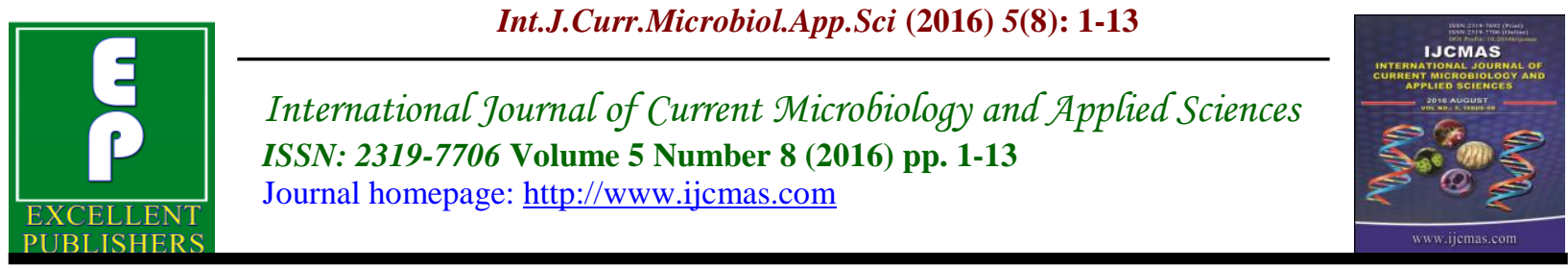

Original Research Article

http://dx.doi.org/10.20546/ijcmas.2016.508.001

\title{
Synthesis and Characterization of New Compounds containing 2-amino Thiazole Ring from Amino Benzoic Acid
}

\author{
Entesar O. Al-Tamimi* and Hussein F. Abdul Mahdi \\ University of Baghdad, college of science, Chemistry department, Baghdad, Iraq \\ *Corresponding author
}

\section{A B S T R A C T}

Keywords

Aminobenzoic

acid,

substituted

aminobenzoate,

hetrocyclic,

thiazol ring.

Article Info

Accepted:

06 July 2016

Available Online:

10 August 2016
The presented work involved the preparation of compounds containing aromatic heterocyclic (thiazol ring) derived from substituted aminobenzoic acid. The first step involved the preparation of substituted esters of aminobenzoic acid (from 1 to 9 compounds) by reaction of substitutedaminobenzoic acid withthionyl chloride then with different alcohols such as (benzyl alcohol, allylalcohol, polyvinyl alcohol).The second step includes the reaction of the prepared compounds with chloroacetyl chloride in the presence of triethylamine to give compounds from (10 to 18). The third step involves the preparation of $\mathrm{N}$-(2-amio thiazole) substituted aminobenzoatefrom the refluxe of cmpounds(10 to 18) with thiourea and DMF. All the prepared compounds in this work were characterized by melting point and softening points with other physical properties, FTIR, $\mathrm{H}^{1}$-NMR spectra.screening of the antimicrobial activity of the prepared thiazol compounds was evaluated against 2 types of bacteria.

\section{Introduction}

Heterocyclic chemistry is one of the largest branches of organic chemistry. It is particularly important in nature because of the wide variety of industrial significance and physiological activities (Bambas, 1952). Heterocyclic compounds with three to six carbons in a single ring are numerous. However, so far, only those with five or six atoms in a single ring are important, such as some of vitamin B complexes, enzymes, amino acids, drugs and the genetic material. The most common hetero atoms are $(\mathrm{N}, \mathrm{O}$, and S). Heterocyclic compounds have received much attention in the development of novel antibacterial (Azab et al., 2013), anthelmintic (Babu, 2013), anticancer (Kaushik et al., 2013) and anti-diabetic activities (Han et al., 2013). These compounds also have industrial applications such accelerators (Unsinn et al., 2013), antioxidants (Malki et al., 2013), copolymers (Paulo et al., 2013), corrosion inhibitors (Nabel et al., 2013) and dyes (Shihab et al., 2013). Thiazole derivatives are an important class of heterocyclic compounds. They occupy an important position in medicinal chemistry, presenting a wide range of bioactivities. As medicines, many of them display including antibacterial and antifungal (Ulusoy et al., 2002; 
Kaplancikli et al., 2004), anti-HIV (AlSaddi et al., 2008), hypertension (Tripathi et al., 2003), anti-inflammatory, anticonvulsant, antidepressant and tubercular activities (Karimain, 2009). Thiazoles and their derivatives have attracted continuing interest over the years because of their varied biological activities. Thiazole, particularly the 2-amino thiazole nucleus have been incorporated into a wide variety of therapeutically interesting candidates.

1. Experimental

2. Material

3. All chemicals used were of analytical grade and there where available from Aldrich and Fluka companies.

4. Instrument

5. Melting points were determined on Gallen Kamp capillary melting point apparatus and were uncorrected.

6. FTIR spectra were recorded on Shimadzu FT-IR 8400 Fourier Transform Infrared Spectrophotometer.

7. Softening points were determined on Thermal Microscope Reichert Thermover 160.

8. ${ }^{1} \mathrm{H}-\mathrm{NMR}$ were measured in DMSO Solutions on a Bruker-500 $\mathrm{MHz}$ spectrophotometer using TMS as an internal standard (chemical shifts in ppm)

9. The antibacterial activity was determined by agar-well diffusion method.

Synthesis methods for the prepared compounds

General procedure for the synthesis of esters

Literature procedure was used with modifications (Karimain et al., 2012).
Thionyl chloride $\left(\mathrm{SOCl}_{2}, 5 \mathrm{~mL}\right)$ was added dropwise to the used alcohol (allyl, benzyl) $\left(5 \mathrm{~mL}, 0{ }^{\circ} \mathrm{C}\right)$ in a round-bottom flask. The solution was stirred for $0.5 \mathrm{~h}$ in ice bath. The amino acid (0.01mole) was dissolved in thionyl chloride $(10 \mathrm{ml})$ and then added to the round-bottom flask. The mixture was refluxed for 6 hours $\left(50^{\circ} \mathrm{C}\right)$. At the end of the reaction, the excess of thionyl was removed under vacuum and the obtained crude product was washed with ether. The physical properties of the prepared compounds are listed in table (1).

General procedure for the synthesis of polyesters

The poly esters were prepared according to the literature with few modifications (Vogel, 1974). (0.01) mole of the amino acid was refluxed with $(10 \mathrm{ml})$ thionyl chloride. Upon the completion (formation of acid chloride) the mixture was transferred to a dropping funnel which is fixed on a bolt-head flask (with condenser) containing ( $0.01 \mathrm{~mole})$ of PVA dissolved in $20 \mathrm{ml}$ DMF. The flask was placed in ice bath and the acid chloride was added dropwise for 30 minute with continuous stirring then the mixture was refluxed for 0.5 hour. The product was poured in water, washed with $5 \%$ sodium bicarbonate, water and then with ethanol and purified by dissolving it in DMSO and reprecipitating it from ethanol. The physical properties of the prepared compounds are listed in table (1).

\section{General procedure for the preparation of} chloroacetyl substituted amides

Literature procedure was used with modifications (21).In100 mL R.B.F the prepared esters (or poly esters) (0.02moles) were dissolved in DMF $(20 \mathrm{~mL})$ then was cooled to $0-5 \circ \mathrm{C}$ and 2-3 drops of TEA were added. Chloroacetylchloride $(0.02 \mathrm{~mole})$ in 
DMF (20 mL) was slowly added to RBF with vigorous stirring for 3 hours. Upon the completion of the reaction the mixture was poured on water $(50 \mathrm{~mL})$ and washed with $5 \% \mathrm{NaHCO} 3$ and subsequently with water. The crude product was dried and recrystallized from ethanol. The physical properties of the prepared compounds are listed in table (2).

\section{General procedure for the preparation of amino thiazol compounds}

Literature procedure was used with modifications (Sujit et al., 2015). In $100 \mathrm{ml}$ R.B.F (0.02mole) of chloroacetyl substituted amides and $(0.02 \mathrm{~mole})$ of thiourea were dissolved in $20 \mathrm{ml} \mathrm{DMF}$ and the mixture was refluxed for 2 hours. Upon the completion the mixture was poured in water and the dry crude product was recrystallized from ethanol (Except the polymers were purified by DMSO). The physical properties of the prepared compounds are listed in table (3).

\section{The Biological activity}

The cup plate method using nutrient agar medium was employed (Chavan et al., 2007;
Al-Azzawi et al., 2010; Carey, 2010) in studying the antibacterial activity of the prepared compounds against two types of bacteria, Staphylococcus aureous(gram positive) and Escherichia coli (Gram negative) respectively using DMSO as sample solution. Using a sterilized cork borer cups were scooped out of agar medium contained in a Petri dish which was previously inoculated with the microorganisms. The test compound solution $(300 \mu \mathrm{l})$ was added in the cups and the Petri dishes were subsequently incubated at $37 \square \mathrm{C}$ for $24 \mathrm{hrs}$. Zones of inhibition produced by each compound was measured in $\mathrm{mm}$ and the results are listed in Table (7).

\section{Result and Discussion}

The starting material for the synthetic N-(2aminothiazol) substituted aminobenzoate is substituted aminobenzoic acid which reacted with different alcohols and thionyl chloride then with chloroacetyl chloride in DMF and after that thiourea was added under reflux. The mechanism is shown in the schemes below.

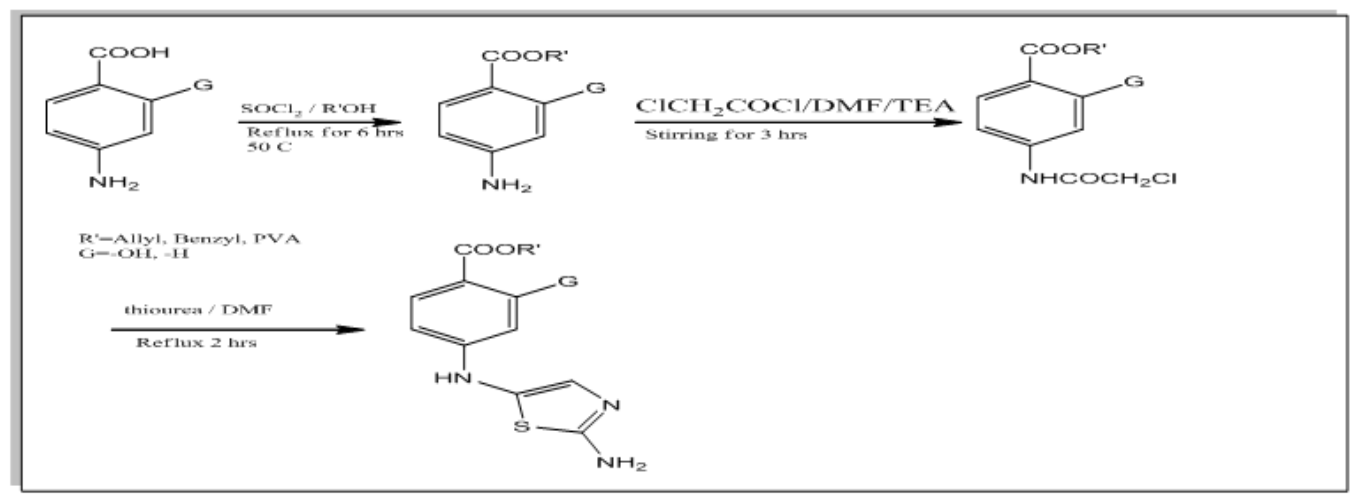

Step1. Ester formation $(25,26)$ : 


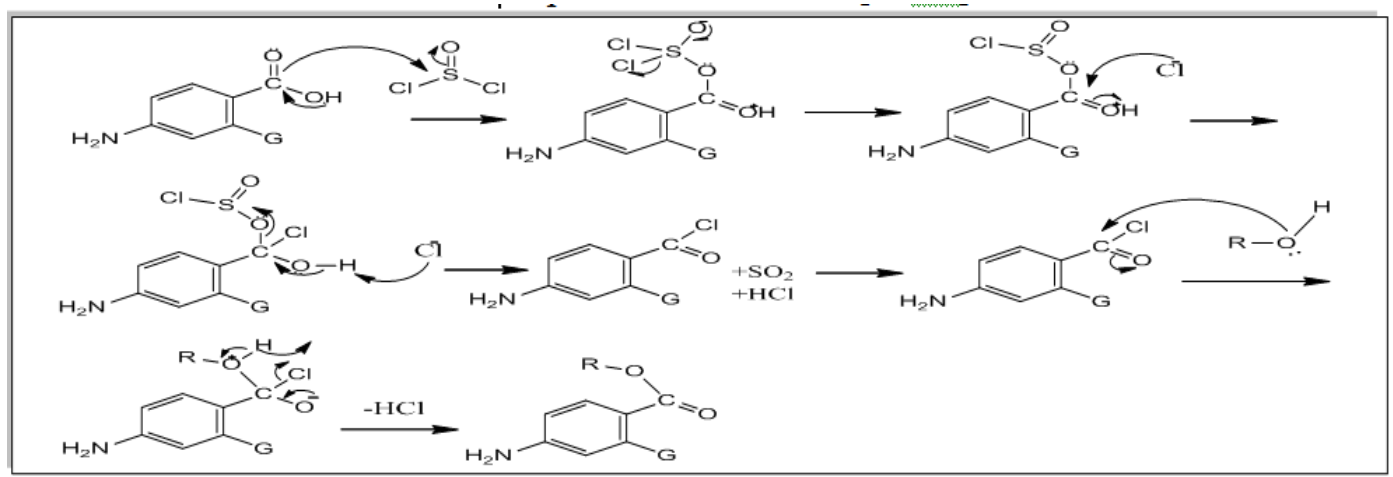

Step2. Chloroacetyl substituted amide formation (27):

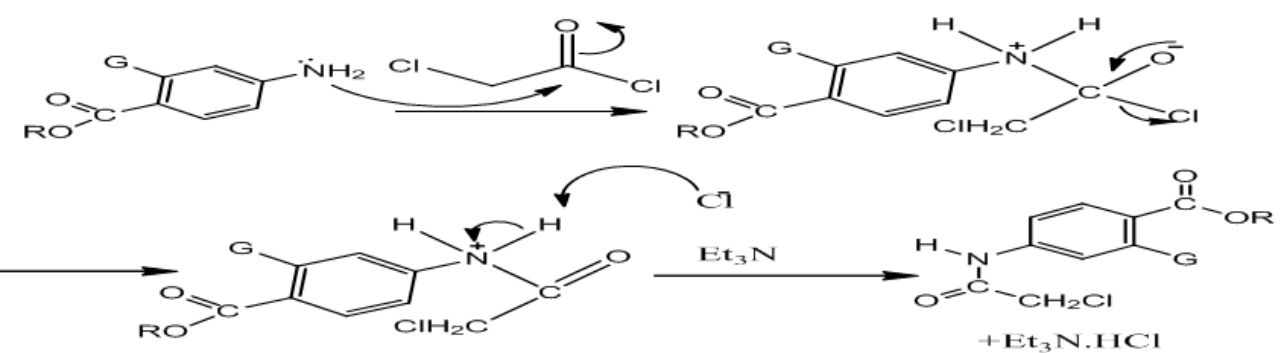

Step3. Formation of 2-aminothiazole ring (28)

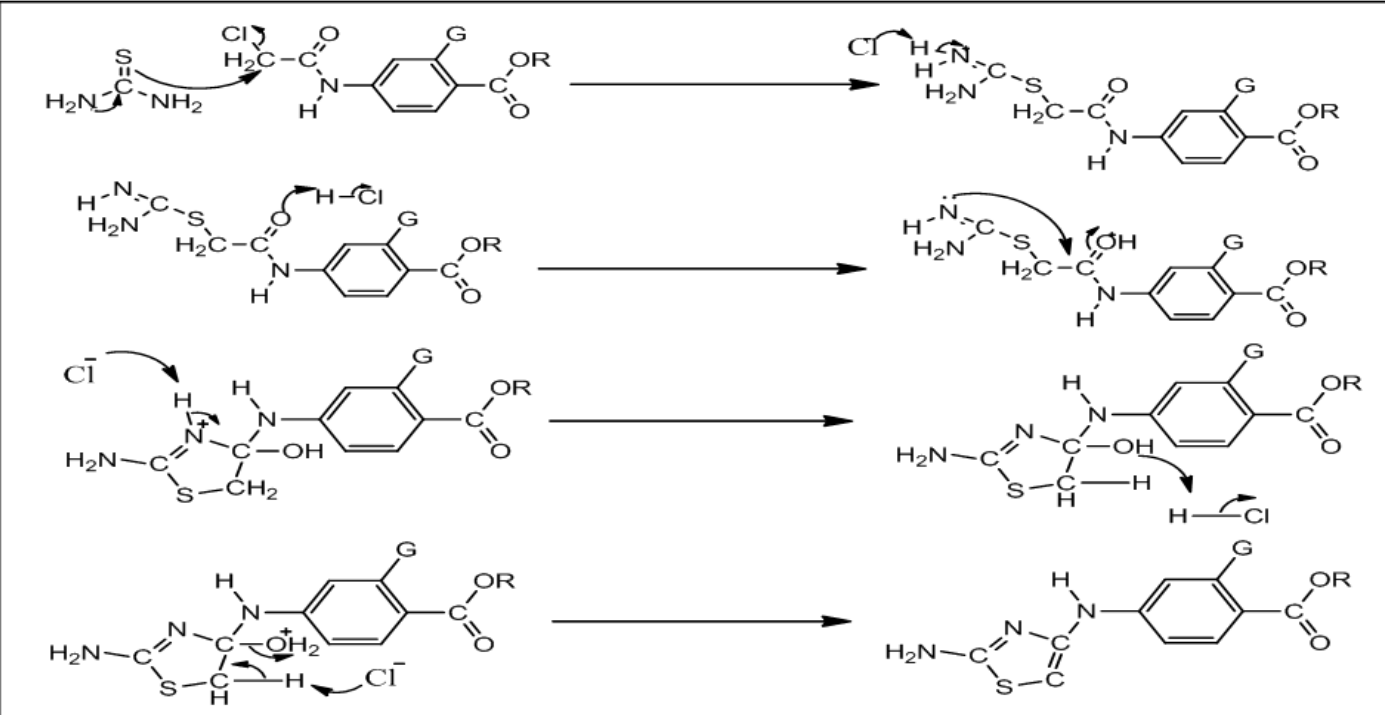

Structures of the prepared compounds in the first step (1-9) were confirmed by physical properties which are listed in table (1).

FTIR spectra showed the absoribtion of the region (3419-3455) cm-1 due to $\left(\mathrm{UNH}_{2}\right)$ group, (1731-1764) cm-1 for ester, (1600-
1550) $\mathrm{cm}-1$ for $(\mathrm{C}=\mathrm{C})$ aromatic, (3048-385) $\mathrm{cm}-1$ for $(\mathrm{C}-\mathrm{H})$ aromatic, $(1340-1378) \mathrm{cm}-1$ for (C-N), (2910-2952) cm-1 for (CH)aliphatic and the absorption for (C-O) $(1190-1256) \mathrm{cm}-1$. All these regions are listed in table(4). 
Table.1 Physical properties of the prepared esters

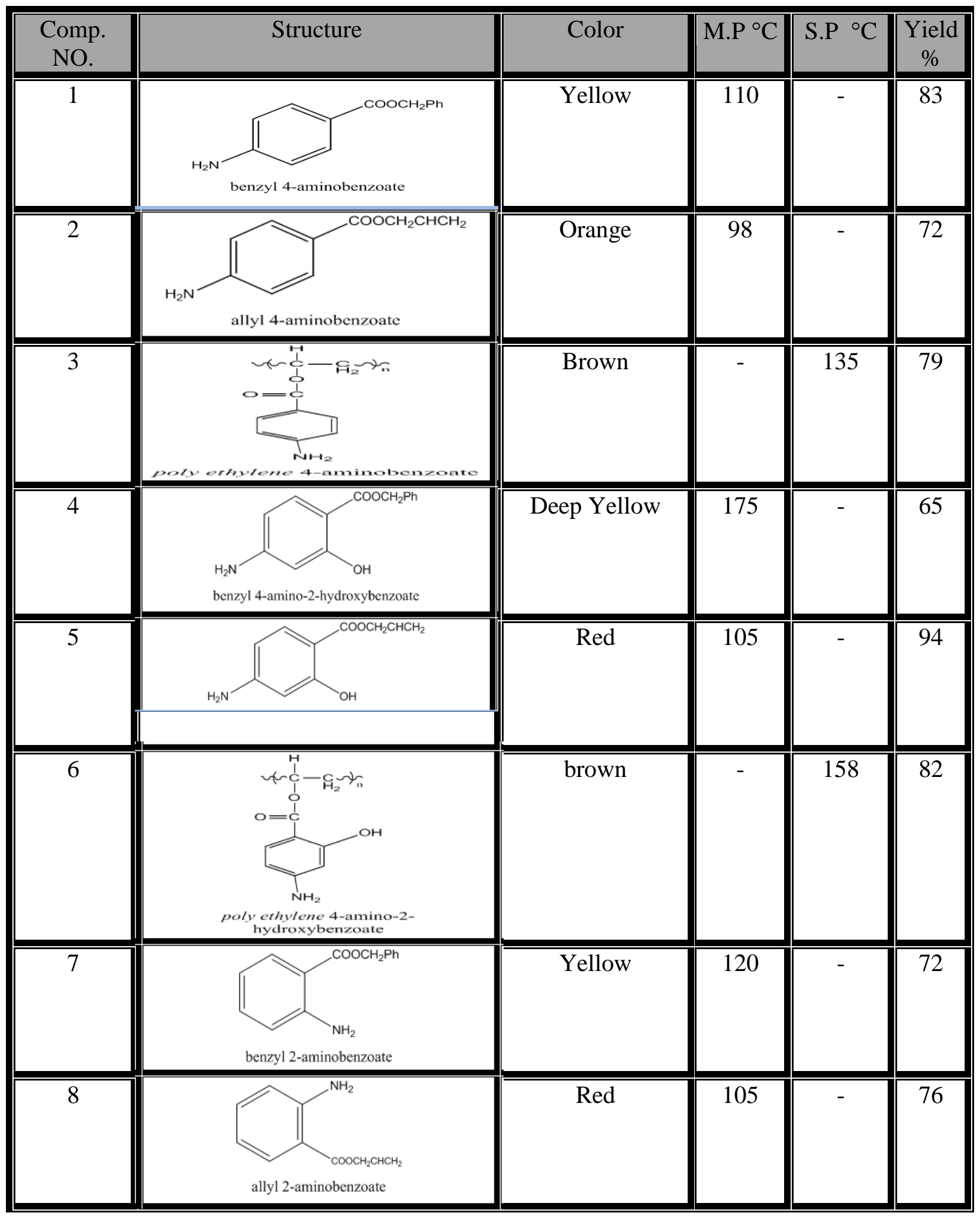




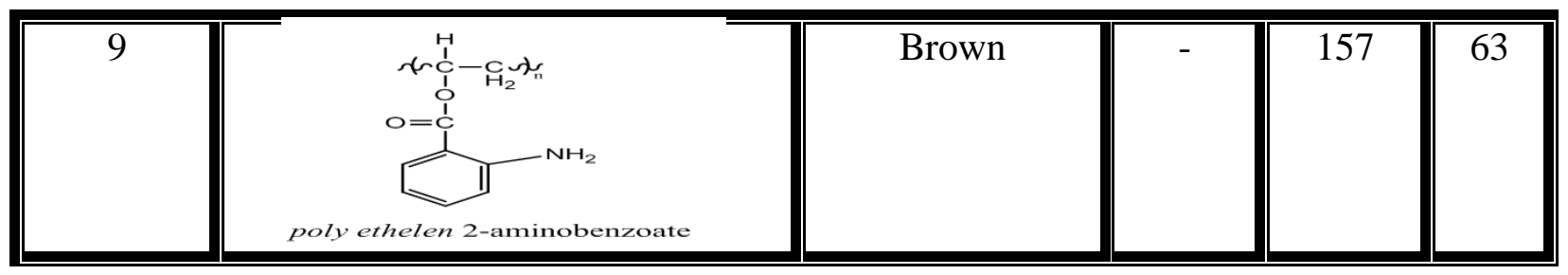

Table.2 Physical properties of the prepared chloroacetyl substituted amides

\begin{tabular}{|c|c|c|c|c|c|}
\hline $\begin{array}{c}\text { Comp. } \\
\text { NO. }\end{array}$ & Structure & Color & M.P ${ }^{\circ} \mathrm{C}$ & $\overline{\text { S.P }}{ }^{\circ} \mathrm{C}$ & $\begin{array}{c}\text { Yield } \\
\%\end{array}$ \\
\hline 10 & benzyl 4-(2-chloroacetamido)benzoate & Deep Yellow & 170 & 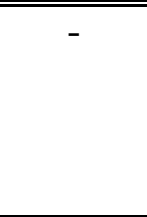 & 64 \\
\hline 11 & allyl 4-(2-chloroacetamido)benzoate & orange & 155 & - & 78 \\
\hline 12 & Poly ethyleme 4-(2- & Dark Brown & - & 167 & 63 \\
\hline 13 & $\underbrace{\mathrm{COOCH}_{2} \mathrm{Ph}}_{\substack{\text { benzyl } \\
\text { 2-(2- } \\
\text { chloroacetamido benzoate }}}$ & Brown & - & - & 80 \\
\hline 14 & allyl 2-(2-chloroacetamido)benzoate & Orange & 92 & - & 60 \\
\hline 15 & 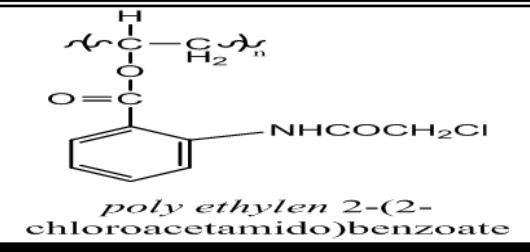 & Dark Brown & - & 136 & $\overline{53}$ \\
\hline 16 & benzyl 4-(2-chloroacetamido)-2-hydroxybenzoate & Brown & 198 & - & 75 \\
\hline
\end{tabular}




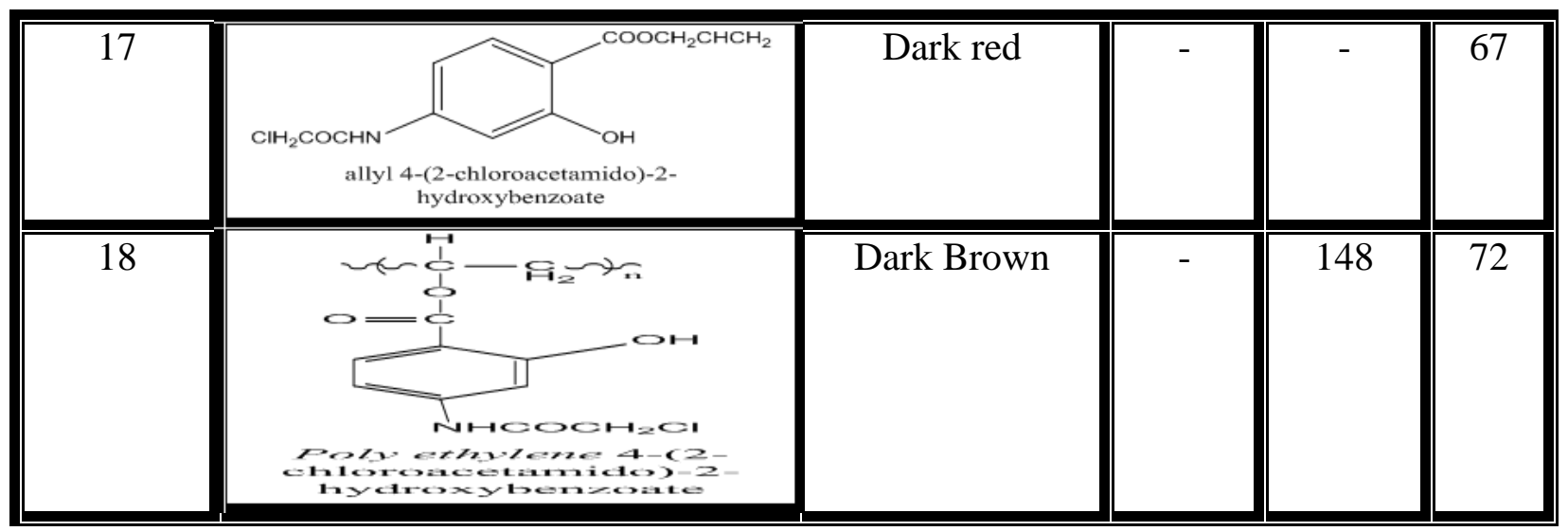

Table.3 Physical properties of the prepared thiazole compounds

\begin{tabular}{|c|c|c|c|c|c|}
\hline $\begin{array}{c}\text { Comp. } \\
\text { NO. }\end{array}$ & Structure & Color & $\begin{array}{c}\text { M.P } \\
{ }^{\circ} \mathrm{C}\end{array}$ & S.P ${ }^{\circ} \mathrm{C}$ & $\begin{array}{c}\text { Yield } \\
\%\end{array}$ \\
\hline 19 & benzyl 4-((2,,5-diaminot & Dark red & 190 & - & 73 \\
\hline 20 & $\begin{array}{l}\mathrm{H}_{2} \mathrm{CHCH}_{2} \mathrm{COOC}^{-} \\
\text {allyl 4-(2,5-diaminothiazo }\end{array}$ & Brown & 172 & - & 78 \\
\hline 21 & poly ethylene 4-(2.5-diamin & Brown & - & 145 & 87 \\
\hline 22 & benzyl 2-(2,5-diaminothi & Dark Red & 108 & - & 76 \\
\hline 23 & allyl 2-(2,5-diaminoth & Brown & 101 & - & 79 \\
\hline
\end{tabular}




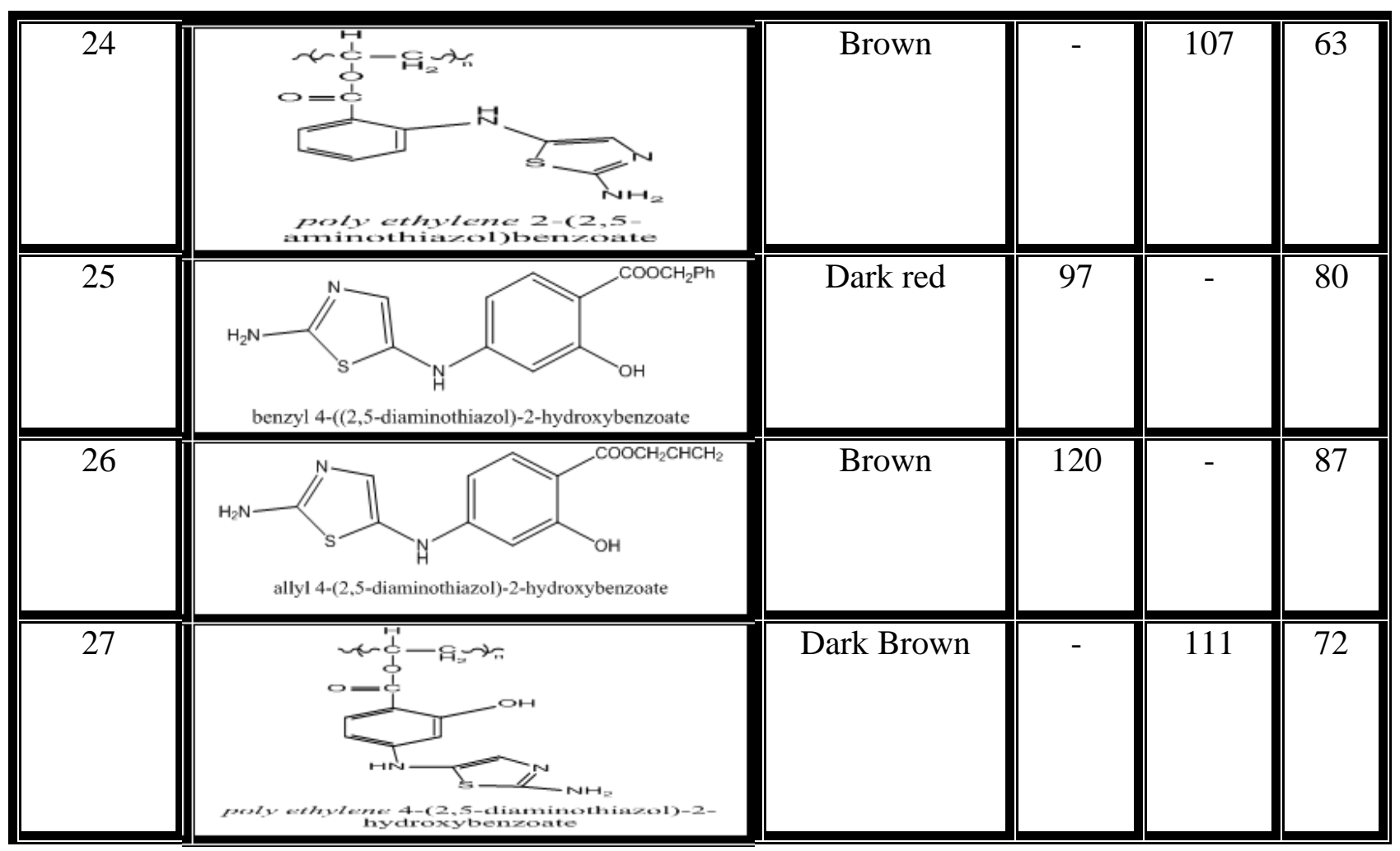

Table.4 FTIR spectra of the prepared esters

\begin{tabular}{|c|c|c|c|c|c|c|c|c|}
\hline $\begin{array}{c}\text { Comp. } \\
\text { No. }\end{array}$ & $\begin{array}{c}\mathrm{vNH}_{2} \\
1^{\circ} \text { amine }\end{array}$ & $\begin{array}{c}\text { uC-H } \\
\text { aromati } \\
\text { c }\end{array}$ & $\begin{array}{c}\text { uC-H } \\
\text { Aliphati } \\
\text { c }\end{array}$ & $\begin{array}{c}\mathrm{vC}=\mathrm{O} \\
\text { ester }\end{array}$ & $\begin{array}{c}\mathrm{UC}=\mathrm{C} \\
\text { aromatic }\end{array}$ & UC-N & uC-O & Others \\
\hline 1 & 3431 & 3052 & 2934 & 1731 & 1600 & 1364 & 1256 & - \\
\hline 2 & 3343 & 3049 & 2932 & 1752 & 1550 & 1369 & 1245 & $\begin{array}{c}\mathrm{vC}=\text { C Olef. } \\
1608\end{array}$ \\
\hline 3 & 3419 & 3053 & 2910 & 1764 & 1614 & 1377 & 1261 & - \\
\hline$\overline{4}$ & 3427 & 3051 & 2952 & 1742 & 1608 & 1371 & 1243 & $\begin{array}{c}\text { vO-H } \\
\text { Phenol } \\
3558 \\
\end{array}$ \\
\hline 5 & 3439 & 3029 & 2918 & 1733 & 1609 & 1340 & 1190 & $\begin{array}{c}\text { uO-H } \\
\text { Phenol } \\
3551 \\
\end{array}$ \\
\hline$\overline{6}$ & 3455 & 3061 & 2922 & 1758 & 1602 & 1352 & 1198 & $\begin{array}{c}\text { vO-H } \\
\text { Phenol } \\
3532 \\
\end{array}$ \\
\hline 7 & 3438 & 3085 & 2936 & 1746 & 1616 & 1368 & 1190 & \\
\hline 8 & 3452 & 3046 & 2965 & 1743 & 1611 & 1373 & 1241 & $\begin{array}{c}\mathrm{vC}=\mathrm{C} \\
\text { Olef.1617 }\end{array}$ \\
\hline 9 & 3435 & 3072 & 2932 & 1761 & 1608 & 1378 & 1221 & \\
\hline
\end{tabular}


Table.5 FTIR spectra of the chloroacetyl substituted amides

\begin{tabular}{|c|c|c|c|c|c|c|c|c|c|c|}
\hline $\begin{array}{l}\text { Com } \\
\text { p.No }\end{array}$ & $\begin{array}{c}\text { uN-H } \\
2^{\circ}{ }^{\circ} \text { amine }\end{array}$ & $\begin{array}{c}\mathrm{vC}-\mathrm{H} \\
\text { aromatic }\end{array}$ & $\begin{array}{c}\text { vC-H } \\
\text { Aliphatic }\end{array}$ & $\begin{array}{c}v \mathrm{C}=\mathrm{O} \\
\text { ester }\end{array}$ & $\begin{array}{l}v C=\mathrm{O} \\
\text { amide }\end{array}$ & $\begin{array}{c}v \mathrm{C}=\mathrm{C} \\
\text { aromatic }\end{array}$ & $\begin{array}{l}v \mathrm{C}- \\
\mathrm{N}\end{array}$ & vC-O & $\begin{array}{c}\text { uC- } \\
\mathrm{Cl}\end{array}$ & others \\
\hline 10 & 3199 & 3012 & 2911 & 1735 & 1681 & $\overline{1607}$ & 1360 & 1250 & $\overline{760}$ & - \\
\hline 11 & 3201 & 3065 & 2941 & $\overline{1761}$ & 1672 & 1610 & 1365 & 1245 & $\overline{745}$ & $\begin{array}{c}\mathrm{vC}=\mathrm{C} \\
\text { Olef. } 1607\end{array}$ \\
\hline 21 & 3234 & 3013 & 2912 & 1724 & 1675 & 1606 & 1379 & 1254 & 767 & - \\
\hline 13 & 3246 & 3086 & 2931 & 1743 & 1679 & 1609 & 1372 & 1247 & 756 & 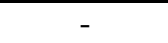 \\
\hline 14 & 3213 & 3034 & 2928 & 1767 & 1668 & 1617 & 1355 & 1180 & 781 & $\begin{array}{l}\text { vC }=C \\
\text { Olef. } \\
1611\end{array}$ \\
\hline 15 & 3212 & 3025 & 2919 & 1769 & 1675 & 1606 & 1371 & 1170 & $\overline{7777}$ & - \\
\hline 16 & 3190 & 3061 & 2931 & 1773 & 1664 & 1619 & 1368 & 11154 & 744 & $\begin{array}{c}\text { vO-H } \\
\text { Phenol } \\
3520\end{array}$ \\
\hline 17 & 3217 & 3056 & 2964 & 1763 & 1677 & 1622 & 1373 & 1234 & 761 & $\begin{array}{c}\text { vO-H } \\
\text { Phenol } \\
3534\end{array}$ \\
\hline 18 & 3213 & 3014 & 2936 & $\overline{1764}$ & 1673 & 1613 & 1369 & 1257 & 7875 & $\begin{array}{c}\text { vO-H } \\
\text { Phenol } \\
3548\end{array}$ \\
\hline
\end{tabular}

Table.6 FTIR Spectra of the 2-aminothiazole compounds in $\mathrm{cm}-1$

\begin{tabular}{|c|c|c|c|c|c|c|c|c|c|c|}
\hline \begin{tabular}{|c|} 
Com \\
p.No
\end{tabular} & $\begin{array}{c}\mathrm{vNH}_{2} \\
1^{\circ} \text { amine }\end{array}$ & $\begin{array}{c}\text { uNH } \\
2^{\circ} \text { amine }\end{array}$ & $\begin{array}{c}\mathrm{uC}-\mathrm{H} \\
\text { aromatic }\end{array}$ & $\begin{array}{c}\text { vC-H } \\
\text { Aliphatic }\end{array}$ & $\begin{array}{c}\mathrm{vC}=\mathrm{O} \\
\text { ester }\end{array}$ & $\begin{array}{c}\mathrm{vC}= \\
\mathrm{N}\end{array}$ & $\begin{array}{c}\mathrm{vC}=\mathrm{C} \\
\text { aromatic }\end{array}$ & $\begin{array}{c}\mathrm{UC}- \\
\mathrm{N}\end{array}$ & vC-O & Others \\
\hline 19 & 3450 & 3210 & 3049 & 2923 & 1785 & 1632 & 1602 & 1368 & 1244 & - \\
\hline 20 & 3332 & 3190 & 3025 & 2921 & 1781 & 1630 & $\overline{1514}$ & 1374 & 1263 & $\begin{array}{c}\mathrm{vC}=\mathrm{C} \text { Olef. } \\
1600\end{array}$ \\
\hline 21 & 3452 & 3224 & 3010 & 2900 & 1766 & 1637 & 1608 & 1373 & 1242 & - \\
\hline 22 & 3444 & 3230 & 3064 & 2927 & 1762 & 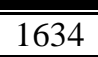 & $\overline{1606}$ & 1375 & 21238 & - \\
\hline 23 & 3456 & 3234 & 3064 & 2923 & 1775 & 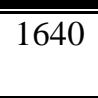 & 1604 & 1323 & 1160 & $\begin{array}{c}v C=C \\
\text { Olef.1608 }\end{array}$ \\
\hline 24 & 3450 & 3192 & 3046 & 2916 & 1770 & 1639 & 1608 & 1369 & 1180 & - \\
\hline 25 & 3450 & 3210 & 3085 & 2954 & $\overline{1776}$ & 21650 & 1612 & 1373 & 1155 & $\begin{array}{c}\mathrm{vO}-\mathrm{H} \\
\text { Phenol } \\
3550\end{array}$ \\
\hline 26 & 3420 & 3200 & 3069 & 2989 & 1755 & $\overline{c 1642}$ & 1620 & 1370 & 1223 & $\begin{array}{c}\mathrm{OO}-\mathrm{H} \\
\text { Phenol } \\
3540\end{array}$ \\
\hline 27 & $\overline{3422}$ & $\overline{3199}$ & $\overline{3062}$ & $\overline{2916}$ & 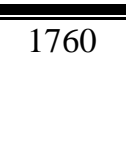 & $\overline{c 1648}$ & $\overline{\overline{1604}}$ & 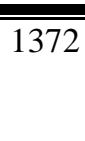 & $\bar{~} 1265$ & $\begin{array}{c}\text { UO-H } \\
\text { Phenol } \\
3542\end{array}$ \\
\hline
\end{tabular}


Table.7 antibacterial activity of the prepared compounds

\begin{tabular}{|c|c|c|}
\hline Comp. No. & $\begin{array}{c}\text { Inhibition Zone against } \\
\text { Stapylococcusaureus (Gram positive) }\end{array}$ & $\begin{array}{c}\text { Inhibition Zone } \\
\text { againstEscherichia coli(Gram } \\
\text { negative) }\end{array}$ \\
\hline \hline $\begin{array}{c}\text { Reference } \\
\text { Cefatoxime }\end{array}$ & $48 \mathrm{~mm}$ & $40 \mathrm{~mm}$ \\
\hline 19 & $30 \mathrm{~mm}$ & $15 \mathrm{~mm}$ \\
\hline \hline 20 & $21 \mathrm{~mm}$ & $12 \mathrm{~mm}$ \\
\hline \hline 22 & $22 \mathrm{~mm}$ & $10 \mathrm{~mm}$ \\
\hline \hline 23 & $20 \mathrm{~mm}$ & $9 \mathrm{~mm}$ \\
\hline \hline 25 & $25 \mathrm{~mm}$ & $8 \mathrm{~mm}$ \\
\hline \hline 26 & $18 \mathrm{~mm}$ & $8 \mathrm{~mm}$ \\
\hline
\end{tabular}

Fig.4 1HNMR spectra of compound 11

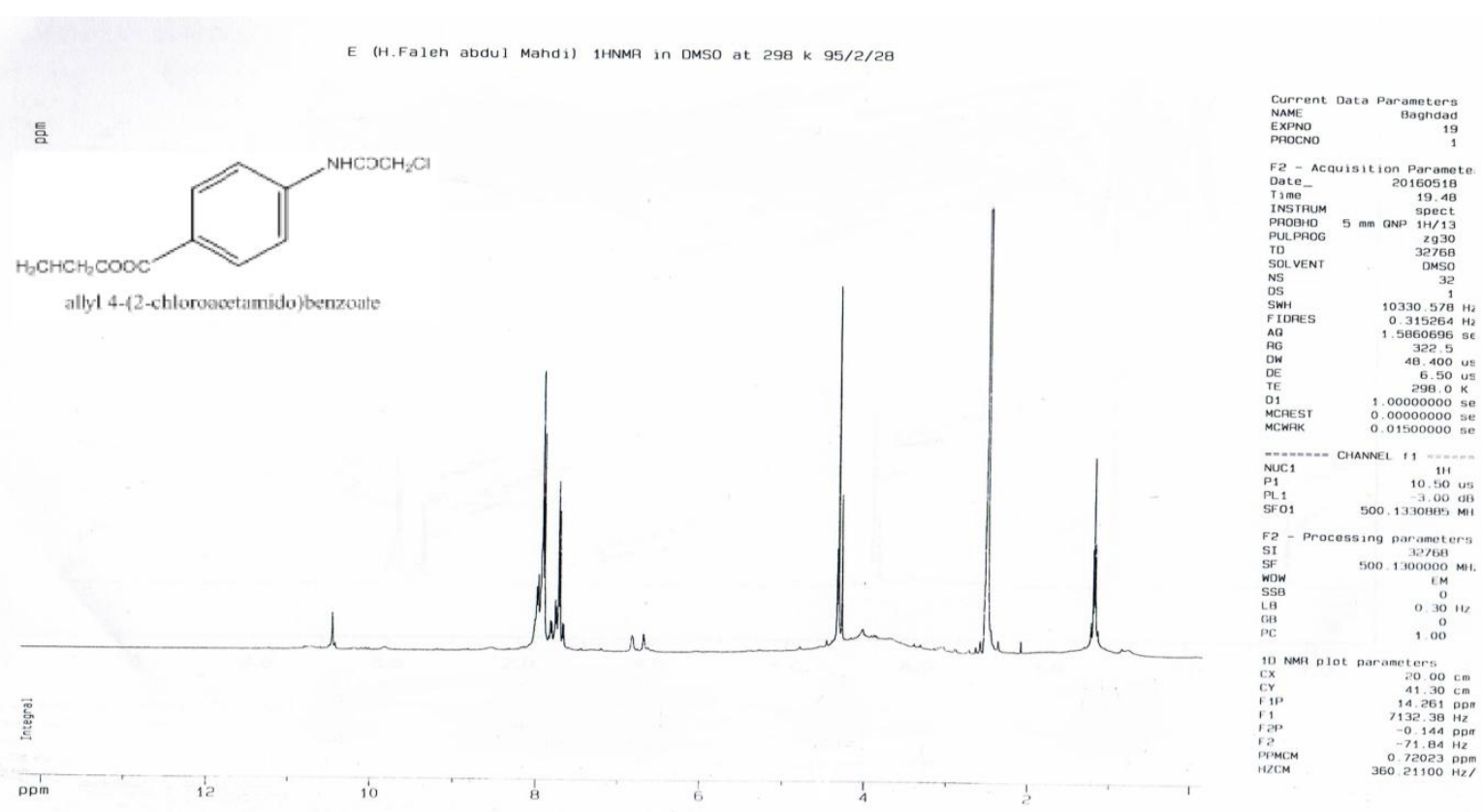


Fig.5 1HNMR spectra of compound 25

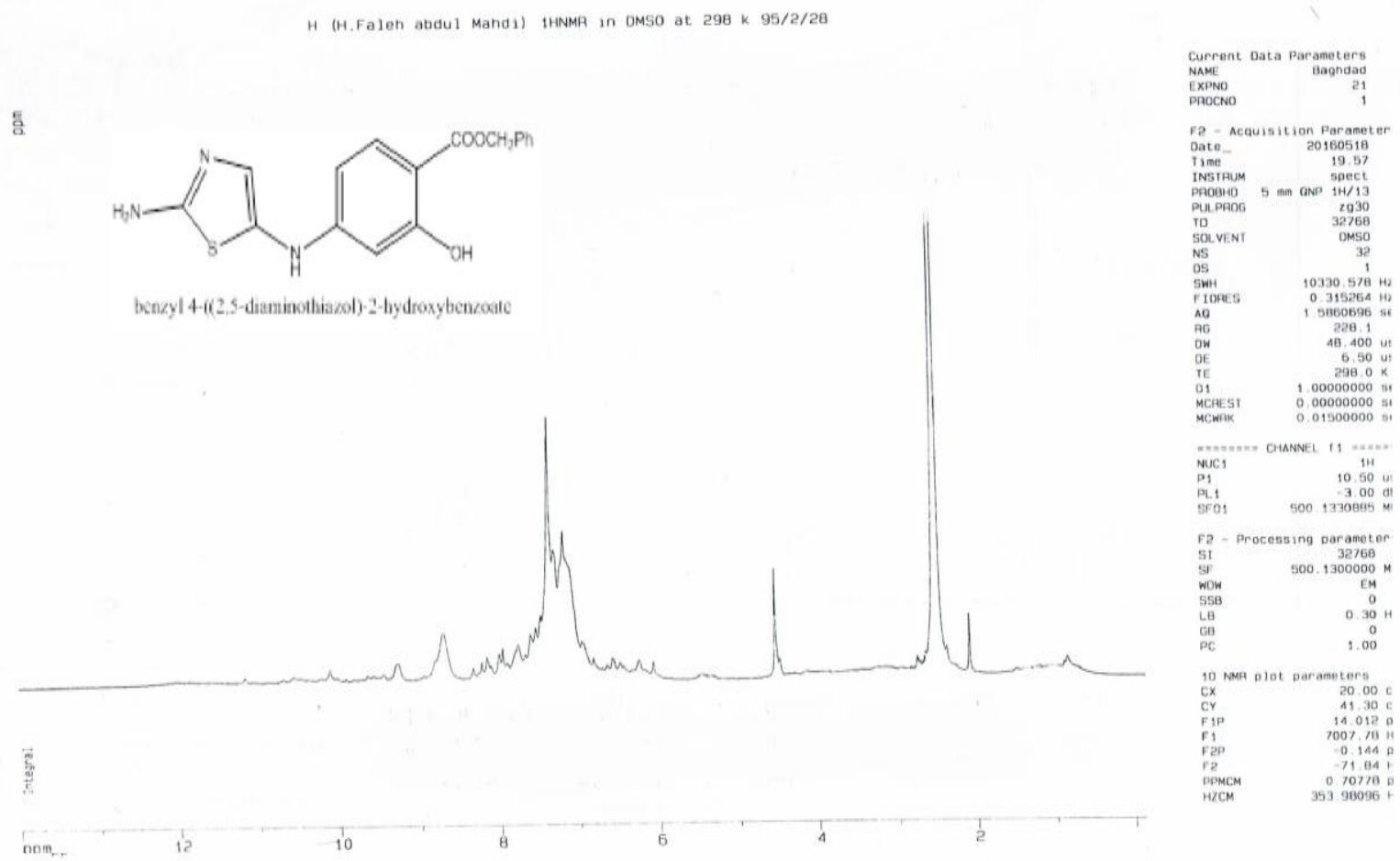

The second step involves the reaction of the prepared compounds (1-9) with chloroacetyl chloride in DMF to produce compounds (1018). The structures were confirmed by the physical properties which are listed in table (2). FTIR spectra showed the disappearance of the absorption band at (3419-3455) cm-1 of $\left(\mathrm{vNH}_{2}\right)$ and the appearance of new region in $(3190-3246) \mathrm{cm}-1$ due to $(\mathrm{vN}-\mathrm{H})$ group, $(1646-1681) \mathrm{cm}-1$ for the $(\mathrm{vC}=\mathrm{O})$ amide and the absorption at (756-781) $\mathrm{cm}-1$ due to the (vC-Cl) group and the other absorptions are listed in table(5).

1H-NMR spectrum of compound 11 showed signals at $\delta 10.4 \mathrm{ppm}$ of $(\mathrm{s}, 1 \mathrm{H}, \mathrm{NH}), \delta 7.9$ ppm of $(\mathrm{m}, 4 \mathrm{H}, \mathrm{Ar}-\mathrm{H}) \quad, \delta 7.5 \quad \mathrm{ppm}$ of $(\mathrm{d}, 1 \mathrm{H},=\mathrm{CH})), \quad \delta 6.8 \quad \mathrm{ppm}$ for the $\left(\mathrm{d}, 2 \mathrm{H}, \underline{\mathrm{CH}}_{2}=\mathrm{CH}-\mathrm{CH}_{3}\right), \quad \delta 4.3 \quad \mathrm{ppm}$ of $\left(\mathrm{d}, 3 \mathrm{H}, \mathrm{CH}_{2}=\mathrm{CH}-\underline{\mathrm{CH}_{3}}\right), \quad \delta 1.3 \quad \mathrm{ppm}$ of (s, $\left.2 \mathrm{H}, \mathrm{CH}_{2} \mathrm{Cl}\right)$.
The third step included the reaction of the prepared compounds (10-18) in DMF at refluxe to produce $\mathrm{N}$-(2-Aminothiazole) substituted aminobenzoate (19-27). The structures of the compounds were confirmed by the physical properties listed in table(3). FTIR of compounds (19-27) showed the disappearance of the absorption band of (vC $=\mathrm{O})$ amide at (1646-1681) cm-1, absorption band of the (uC-Cl) group at (756-781) cm-1 which confirms the conversion to the final product, and the appearance of new band at (3420-3456) cm1 of $\left(\mathrm{NH}_{2}\right)$ group and new absorption at $(1630-1650) \mathrm{cm}-1$ of $(\mathrm{vC}=\mathrm{N})$ group and the other absoribtions are listed in table (6).

1H-NMR spectrum of compound 25 showed signal at $\delta 10.1 \mathrm{ppm}$ for $(\mathrm{s}, 1 \mathrm{H}, \mathrm{OH}), \delta 9.3 \mathrm{ppm}$ for $\left(\mathrm{s}, 2 \mathrm{H}, \mathrm{NH}_{2}\right), \quad \delta 8.6 \mathrm{ppm}$ for $(\mathrm{s}, 1 \mathrm{H}, \mathrm{NH})$, $7.3 \mathrm{ppm}$ for $(\mathrm{m}, 4 \mathrm{H}, \mathrm{Ar}-\mathrm{H}), \delta \quad 4.5 \mathrm{ppm}$ (s, $1 \mathrm{H}, \mathrm{CH}$ thiazole ring) 


\section{References}

Al-Azzawi, A.M. and Mehdi, S.A. 2010. Baghdad Sci. J., 7(1): 641.

Al-Saddi, M.S., Faidallah, H.M., Rostom, S.A.F. 2008. Arch. Pharm. Che. Life Sci., 341: 424-434.

Azab, M., Youssef, M. and. El-Bordany, E. 2013. (Synthesis and Antibacterial Evaluation of Novel Heterocyclic Compounds Containing a Sulfonamido Moiety) Mol., 18: 832844.

Babu, I. and Selvakumar, S. 2013. (Synthesis and spectral characterization of some 2-((1((substituted phenylamino)methyl)1-benzoimidazol-2-yl) alkyl) isoindoline-1,3-diones for in-vitro anthelmintic screening) Der. Pharma. Chemica, 5(4): 198-206.

Bambas, L. 1952. (Five-membered heterocyclic compounds with nitrogen and sulfur or nitrogen, sulfur and oxygen (except thiazole)) 2nd ed., Parke, Davis and company, Detroit, Michigan, USA.

Baselt, T., Rehse, K. 2008. Archived der pharmazie, 24: 645-654.

Ber Dtsch. 1887. Chem. Ges., 20: 3118.

Carey, F.A. 2010. "Organic chemistry", $7^{\text {th }}$ Ed. RajkamalElectic press, New Delhi, PP(482,489,500,708).

Chavan, A.A. and Pai, N.R. 2007. Mol., 12: 2467.

Fuson, Cruth, Morril. 1980. "the systematic identification of organic compounds" $6{ }^{\text {th }}$ Ed. P.167.

Han, J., Dong, H., Xu, Z., Wang, J. and Wang, M. 2013. (Synthesis and Activity of Novel Acylthiourea with Hydantoin) Int. J. Mol. Sci., 14:19526-19539.

Jiaxi, X. 2009. "Steriochemistryin the synthesis from ketens and imines by Staudinger reaction", $5^{\text {th }}$ Eurasian conference on hetrocyclic chemistry: 21-44. USA, INC.

Kaplancikli, Z.A., Zitouni, G.T., Revial, G., Guven, K. 2004. Arch. Pharm. Res., 27: 1081- 1085.

Karade, H.N., Acharya, B.N., Manisha, S., Kaushik, M.P. 2008. Med. Chem. Res., 19-29.

Karimain, K. 2009. Indian J. Chem., 19: 369-371.

Karpov, K.A., Nazarenko, A.V., Pekarevskii, B.V., potekhin, V.M. 2001. Russian J. Appl. Chem., 74: 998-1001.

Kaushik, K., Ashok, G., Swati, D., Mustafa, K. and Hiral, T. 2013. (Benzimidazole: apromising lead for anticancer drug design) Uni. J. Pharm., 2(3): 57-62.

Malki, F., Touati, A. and Moulay, S. 2013. (Antioxidant Activity of Two Mesomeric Heterocyclic Betaines Containing a Pyrimidine Moiety) $J$. Trop. Agric. Sci., 36(4): 393-402.

Modi, B.R., Vashi, D.M., and Desai, K.R. 1994. "Synthesis of 8triazinylamino coumarin derivatives and their fluorescent properties," Indian J. Chem. Technol., vol. 1, no. 5, pp. 317-318.

Nabel, A., Negm, Mona, A. and Tawfik, S. 2013. (Impact of Synthesized and Natural Compounds in Corrosion Inhibition of Carbon Steel and Aluminium in Acidic Media) Recent Patents on Corrosion Sci., 3: 1-11.

Paulo, J., Coelho, A., Céu, M., Sousa, M., Cidália, R., Castro, A., Maurício, C., Fonseca, M., Manuela, M. and Raposo, P. 2013. (Fast thermal cistrans isomerization of heterocyclic azo dyes in PMMA polymers) Optical Materials, 35: 1167-1172.

Shihab, N. and Intedhar, M. 2013. (Synthesis of some novel heterocyclic azo dyes for acridine 
derivatives and evaluation of their antibacterial activities) J. Chema. \&Pharma. Res., 5(5): 345-354.

Sujit, K., Anuradha, K., Harika, M., Sarada, P. and Jenny, S. 2015. (Synthesis, Characterization and Antimicrobial Activity of Some Oxazole and Thiazole Derivatives) J. Serb. Chem. Soc., 2(3): 60-66.

Tang, X., Guangxia Tang, Wang, H., LuoL, and Yang, D. 2012. Bull. Chem. Soc. Ethiop., 26(3): 415-420.

Tripathi, K.D. 2003. Essential of medical pharmacology., 5th edition, 627-686.
Ulusoy, N., Kiraz, M., Kucukbasmaci. O., 2002. Monatshefte fur chemie. 133: 1305-1315.

Unsinn, A., Stefan, H., Wunderlich and Knochel, P. 2013. (Accelerated Zincations for an Efficient and Mild Functionalization of Aromatics and Heterocycles) Adv. Synthesis \& Catalysis, 355(5): 989-995.

Vogel, A.I. 1974. "A text book in practical organic chemistry" $3^{\text {rd }} \mathrm{Ed}$ Iongman group limited, London, pp.389.

\section{How to cite this article:}

Entesar O. Al-Tamimi and Hussein F. Abdul Mahdi. 2016. Synthesis and Characterization of New Compounds containing 2-amino Thiazole Ring from Amino Benzoic Acid. Int.J.Curr.Microbiol.App.Sci. 5(8): 1-13. doi: http://dx.doi.org/10.20546/ijcmas.2016.508.001 